\title{
Synthesis and Absorption Spectral Properties of Bis-methine Dyes Exemplified by 2,5 -Bis-arylidene-1-dicyanomethylene-cyclopentanes
}

\author{
Abdullah Mohamed Asiri

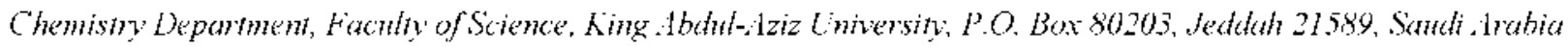 \\ Received tovenber 25,2002

\begin{abstract}
A range of methine dyes has been synthesized by condensation of highly electronegative active methylene compound diey anomethy lenecyclopentane derived from cyclopentanone with the lomyl group of suthstituled benzaldehy des. The electronic absorption spectroseopie properties of the dyes were investigated. In general, substituents on the aromatie aldehyde moiety have a signifieant effect on the visible absorption maxima of the dyes; increasing the solvent polarity also shened a pronounced eflect on the absorption maxima.
\end{abstract}

Key Words : Bis-methine dyes. Malononitrile, Cyclopentanone, Dicy anomethy lenecyclopentane, Chalcones

\section{Introduction}

A broad class of dyestuff and colorants are based on electron donor-acceplor (D- $\pi$-A) cliromogens. Such compounds have found many applications such as in dyeing of fabric. coloring of toners. and in image forming and optical information storage technologies. Some of these compounds are also used as sources of tunable (dyc laser) radiation. ${ }^{1-7}$

Methine dyes (e.g. 2) based on indant-1.3-dione 1a are typical donor-acceptor chromogens and are generally yellow to orange in colour with high absorption intensity.

Replacement of the oxygen of one of the carbonyl groups in $2 a$ by a more powerful clectron acceptor dicyanomelhylenc groups give dye $\mathbf{2 b}$. which has absorption maximum at much longer wavelengtlss with some reduction in intensity." Further modification of dic $\mathbf{2 b}$ by replacing the second carbonyl group by dicyanomelly lene group (e.g. 2c). results<smiles>[B]=C1CC(=C)c2ccccc21</smiles>

1

$$
\begin{array}{r|l}
1,2 & \\
\hline \mathbf{a} & A=B=0 \\
\mathbf{b} & A=O, B=C(C N)_{2} \\
\mathbf{c} & A=B=C(C N)_{2}
\end{array}
$$<smiles>O=C1CCc2ccccc21</smiles>

3<smiles>[B]C1C(=Cc2ccc(N(C)C)cc2)C2=CC=CC21</smiles>

2

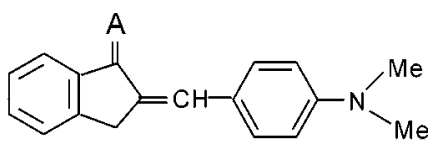

4

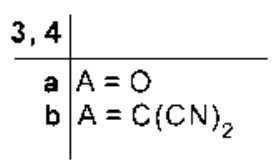

"Phonc: +966-2-6952293, Fax: +966-2-6952293, E-mail: a_asiri iatholmail.com in dyes will absorption up to $625 \mathrm{~nm}$."

Recently: we lave reported the synthesis of new dyes ta and $+\mathrm{b}$ by condensation of 1 -indanone $3 \mathrm{a}$ and 1 -dicyanomethy leneindane $3 \mathbf{b}$ and aromatic aldehydes. ${ }^{14}$

Dyc th absorbs at shorter wavelength than $2 \mathrm{~b}$ by some 84 ntm and some $46 \mathrm{~nm}$ to longer warelength than 2 a. In the present investigation. the synthesis. colour and constitution of new dyes 7a-g prepared by condensation of dicyanomethy lenecyclopentane 5 and aromatic aldehydes will be discussed.

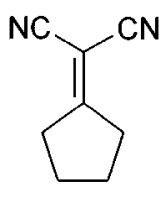

5

6,7<smiles>O=C1C(=CBr)CCC1=CBr</smiles>

6<smiles>N#CC(C#N)=C1/C(=C\[Al])CC/C1=C/[125I]</smiles>

7

\begin{tabular}{lll}
\hline a & $4-\mathrm{Me}_{2} \mathrm{~N}-\mathrm{C}_{6} \mathrm{H}_{4}$ & \\
b & $2-\mathrm{MeO}-\mathrm{C}_{6} \mathrm{H}_{4}$ & \\
c & $3,4-(\mathrm{MeO})_{2} \mathrm{C}_{6} \mathrm{H}_{3}$ \\
d & $2,5-(\mathrm{MeO})_{2} \mathrm{C}_{6} \mathrm{H}_{3}$ \\
e & $3,4-\mathrm{OCH}_{2} \mathrm{O}-\mathrm{C}_{6} \mathrm{H}_{3}$ & g,
\end{tabular}

\section{Results and Discussion}

Synthesis of dyes. Chalcones 6a-g were prepared wa Aldol condensation of 1-cyclopentanone and appropriate aldelydes (Table 1). When chalcone 6a and malononitrile were leated under reflux in the presence of ammonium acetatc. gave exclusively the pyridine derivative 8 shown in Scheme 1 . This is in agrecment with similar observations reported in the literature. ${ }^{11}$

The IR spectrum of the pyridine derivatives 8 showed absorption bands at $3350.3227 \mathrm{~cm}{ }^{3}$ and an absorption band at $2215 \mathrm{~cm}{ }^{1}$ for amino and cyano groups respectively.

It las been reported in the literature that $\alpha . \beta$-unsaturated 
Table 1. Characterization Data of Chalcones 6a-g

\begin{tabular}{|c|c|c|c|c|c|c|}
\hline \multirow{2}{*}{$\begin{array}{l}\text { 1)e } \\
\text { No. }\end{array}$} & \multirow{2}{*}{$\begin{array}{l}\text { Yield } \\
\left(v^{*}{ }^{\prime}\right)\end{array}$} & \multirow{2}{*}{$\begin{array}{l}\text { m.p. } \\
\text { ("c) }\end{array}$} & \multirow{2}{*}{$\begin{array}{l}\text { Molecular } \\
\text { formula }\end{array}$} & \multicolumn{3}{|c|}{$\left({ }^{\prime}{ }^{\prime}\right)$ liound (culculated) } \\
\hline & & & & C & 11 & N \\
\hline $6 a$ & 63 & 120 & $\mathrm{C}_{23} \mathrm{H}_{2} \mathrm{~N}_{2} \mathrm{O}$ & $\begin{array}{c}79.52 \\
(79.77)\end{array}$ & $\begin{array}{c}7.85 \\
(7.51)\end{array}$ & $\begin{array}{c}7.85 \\
(8.09)\end{array}$ \\
\hline $6 b$ & 67 & 155 & $\mathrm{C}_{21} \mathrm{H}_{20} \mathrm{O}_{3}$ & $\begin{array}{c}78.63 \\
(78.75)\end{array}$ & $\begin{array}{c}5.98 \\
(6.25)\end{array}$ & \\
\hline $6 c$ & 66 & 157 & $\mathrm{C}_{23} \mathrm{II}_{2+} \mathrm{O}_{5}$ & $\begin{array}{c}72.49 \\
(72.63)\end{array}$ & $\begin{array}{c}6.28 \\
(6.32)\end{array}$ & \\
\hline $6 \mathrm{~d}$ & 88 & $2] 0$ & $\left(\mathrm{C}_{23} \mathrm{I}_{2+}\left(\mathrm{O}_{5}\right.\right.$ & $\begin{array}{c}72.52 \\
(72.63)\end{array}$ & $\begin{array}{c}6.43 \\
(6.32)\end{array}$ & \\
\hline Ge & 44 & 250 & $\mathrm{C}_{21} \mathrm{~J}_{1 \mathrm{~K}}\left(\mathrm{O}_{5}\right.$ & $\begin{array}{c}72.51 \\
(72.41)\end{array}$ & $\begin{array}{c}4.43 \\
(4.6(1))\end{array}$ & \\
\hline $6 \mathrm{f}$ & 55 & 140 & $\mathrm{C}_{15} \mathrm{~J}_{12} \mathrm{~S}_{2} \mathrm{O}$ & $\begin{array}{c}65.87 \\
(60.17)\end{array}$ & $\begin{array}{c}4.67 \\
(4.41)\end{array}$ & \\
\hline $6 \mathrm{~g}$ & 77 & 170 & $\mathrm{C}_{23} \mathrm{IH}_{1 S} \mathrm{~N}_{2} \mathrm{O}_{2}$ & $\begin{array}{c}81.46 \\
(81.65)\end{array}$ & $\begin{array}{c}5.51 \\
(5.33)\end{array}$ & $\begin{array}{c}8.36 \\
(8.23)\end{array}$ \\
\hline
\end{tabular}

ketones. when heated with malononitrile in benzene using a catalytic amount of ammonum acetate-acetic acid as a base under a Deanstark trap. gave the desired Knoevenagel condensation product. ${ }^{12,13}$ However, heating under reflux for 8 lurs the chalcone 6a. malonouitrile and ammonium acetateacetic acid in benzene gave $7 \mathbf{a}$ as shown in Scheme 2 in very low yield. The low yield of Knoevenagel product $7 a$ promoted us to look for an alternative procedure to obtain a better yield.

Among those procedures a solid state Knoevenagel reaction which reported in 1993 in which a catalytic amount of CdI was used as a catalyst. ${ }^{14}$ Moreover, when the reaction was carried in ethanol in the presence of piperidine as a base. 4 H-py rane denvative 9 was obtained as yellow crystals in good yield (Scheme 2). In this case. the Knoevenagel condensation was not taking place but the Michael addition was facilitated. On the other land. if the highly electronegative active methylene 5 was condensed with benzaldehydes such as 4-dimethylanuinobenzaldelyyde in ethanol or in THF no Knoevenagel products were identified.

However, a reasonable yield of dyes $7 \mathbf{a - g}$ was obtained when the dicyanomethy lenecyclopetane 5 and the aromatic aldehyde were fused at $140^{\circ} \mathrm{C}$ for about three hours. This procedure was adopted for the synthesis of dyes $7 \mathrm{a}-\mathrm{g}$. analytical data for which are summarized in Table 1. Dyes 7a-g exhibited CN absorption bands in their IR spectra in the region of $2205-2230 \mathrm{~cm}^{-1}$ (Table 3). and their ${ }^{1} \mathrm{H}-\mathrm{NMR}$ spectra showed a down field singlet in the region of $\delta 7.0-8.0$ ppm. attributed to olefinic protons (Table 4 ). ${ }^{1.3} \mathrm{C}-\mathrm{NMR}$ data are summarized in Table 5.

Electronic absorption spectroscopic properties. Absorption spectra were recorded in chloroform. acetone and acetonitrile: the results obtained are summarized in Table 6. Dye 7a. which was obtained from 4-dimethy laminobenzaldehyde and compound 5. absorbs at $542 \mathrm{~lm}$ in chloroform, with molar extinction coefficient of $5000 \mathrm{dm}^{3} \cdot \mathrm{mol}^{-1} \mathrm{~cm}^{-1}$. Changing the donor from dimethy lamino to methoxy group as for dye $7 \mathbf{b}$. which prepared from 2-methosybenzaldehyde.<smiles>CN(C)c1ccc(/C=C2\CC/C(=C\c3ccc(N(C)C)cc3)C2=O)cc1</smiles>

$6 a$

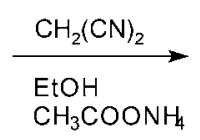

Scheme 1<smiles>CN(C)c1ccc(/C=C2\CCc3c2nc(N)c(C#N)c3-c2ccc(N(C)C)cc2)cc1</smiles>

8 $\mathrm{Me}^{\prime} \mathrm{Me}$<smiles>CN(C)c1ccc(/C=C2\CC/C(=C\c3ccc(N(C)C)cc3)C2=O)cc1</smiles>

$6 a$

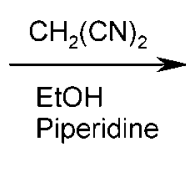<smiles>CN(C)c1ccc(/C=C2\CCC3=C(C2)OC(N)=C(C#N)C3(c2ccccc2)c2ccc(N(C)C)cc2)cc1</smiles>

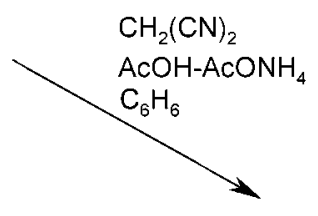<smiles>CN(C)c1ccc(/C=C2\CC/C(=C\c3ccc(N(C)C)cc3)C2=C(C#N)C#N)cc1</smiles>

$7 a$ 
Table 2. Characterization Data of Dyes 7a-g

\begin{tabular}{|c|c|c|c|c|c|c|}
\hline \multirow{2}{*}{$\begin{array}{l}\text { Dye } \\
\text { No. }\end{array}$} & \multirow{2}{*}{$\begin{array}{l}\text { Yield } \\
\left({ }^{0}{ }_{0}\right)\end{array}$} & \multirow{2}{*}{$\begin{array}{l}\text { m.p. } \\
\left({ }^{\circ} \mathrm{C}\right)\end{array}$} & \multirow{2}{*}{$\begin{array}{l}\text { Molecular } \\
\text { formula }\end{array}$} & \multicolumn{3}{|c|}{$\left(0_{0}\right)$ Found (calculated) } \\
\hline & & & & C & $\mathrm{H}$ & $\mathrm{N}$ \\
\hline $7 a$ & 16 & 233 & $\mathrm{C}_{26} \mathrm{H}_{2} \mathrm{~N}_{1} \mathrm{O}_{4}$ & $\begin{array}{c}77.95 \\
(78.18)\end{array}$ & $\begin{array}{c}6.31 \\
(6.59)\end{array}$ & $\begin{array}{c}14.01 \\
(14.21)\end{array}$ \\
\hline $7 \mathbf{b}$ & 67 & 122 & $\mathrm{C}_{2.4} \mathrm{H}_{20} \mathrm{~N}_{2} \mathrm{O}_{2}$ & $\begin{array}{c}78.04 \\
(78.26)\end{array}$ & $\begin{array}{c}5.68 \\
(5.43)\end{array}$ & $\begin{array}{c}7.39 \\
(7.61)\end{array}$ \\
\hline $7 c$ & 66 & 125 & $\mathrm{C}_{26} \mathrm{H}_{2} \mathrm{~N}_{2} \mathrm{O}_{4}$ & $\begin{array}{c}72.64 \\
(72.89)\end{array}$ & $\begin{array}{c}5.46 \\
(5.60)\end{array}$ & $\begin{array}{c}6.61 \\
(6.54)\end{array}$ \\
\hline $7 d$ & 75 & 199 & $\mathrm{C}_{26} \mathrm{H}_{2} \mathrm{~N}_{2} \mathrm{O}_{4}$ & $\begin{array}{l}72.68 \\
(72.89)\end{array}$ & $\begin{array}{c}5.46 \\
(5.60)\end{array}$ & $\begin{array}{c}6.38 \\
(6.54)\end{array}$ \\
\hline $7 e$ & 44 & 189 & $\mathrm{C}_{23} \mathrm{H}_{13} \mathrm{~N}_{2} \mathrm{O}_{2}$ & $\begin{array}{c}72.43 \\
(72.72)\end{array}$ & $\begin{array}{c}4.25 \\
(4.1 k)\end{array}$ & $\begin{array}{c}6.85 \\
(7.07)\end{array}$ \\
\hline $7 \mathbf{f}$ & 55 & 168 & $\mathrm{C}_{1 S} \mathrm{I}_{13} \mathrm{~N}_{3} \mathrm{~S}_{2}$ & $\begin{array}{c}67.43 \\
(67.5(1)\end{array}$ & $\begin{array}{c}3.64 \\
(3.75)\end{array}$ & $\begin{array}{c}8.56 \\
(8.75)\end{array}$ \\
\hline $7 g$ & 77 & ] 89 & $\mathrm{C}_{2 \times} \mathrm{IH}_{18} \mathrm{~N}_{4}$ & $\begin{array}{c}80.68 \\
(80.82)\end{array}$ & $\begin{array}{c}1.54 \\
(1.66)\end{array}$ & $\begin{array}{c}14.32 \\
(14.5())\end{array}$ \\
\hline
\end{tabular}

Table 3. IR Spectral Data of Chalcones 6a-g and Dyes 7a-g

\begin{tabular}{|c|c|c|c|c|}
\hline \multirow{3}{*}{$\begin{array}{l}\text { Intry } \\
\text { No. }\end{array}$} & \multicolumn{4}{|c|}{$V_{\max }\left(\mathrm{cos}^{-1}\right)$} \\
\hline & \multicolumn{2}{|c|}{6} & \multicolumn{2}{|c|}{7} \\
\hline & $C-C$ & $\mathrm{C}-\mathrm{O}$ & $C^{-}-C$ & $\mathrm{CN}$ \\
\hline a & 1589 & 1689 & 1607 & 2175 \\
\hline b & 1594 & 1679 & 1657 & 2225 \\
\hline c & 1597 & ] 680 & 1645 & 2207 \\
\hline d & 1616 & 1708 & 1640 & 2206 \\
\hline e & 1597 & 1682 & 1657 & 2224 \\
\hline f & 1589 & 1649 & 1657 & 2225 \\
\hline $\mathrm{g}$ & 1609 & 1682 & 16.37 & $22 t) 3$ \\
\hline
\end{tabular}

Talble +. 'H-NMR-Data of Chalcones Ga-g and Their' Analogues Dicranomethrlene Derivatives $7 \mathbf{a}-\mathrm{g}$

\begin{tabular}{|c|c|c|c|c|}
\hline $\begin{array}{c}\text { Compound } \\
\text { No. }\end{array}$ & $-\left(\mathrm{Cll}_{2}\right)-$ & $\begin{array}{c}\text { Aromatic } \\
\text { protons }\end{array}$ & $\begin{array}{l}\text { Olitinc } \\
\text { protons }\end{array}$ & Others \\
\hline $6 a$ & 3.02 & $6.78-7.38$ & 7.71 & $304\left(\mathrm{CII}_{3}\right)=\mathrm{N}$ \\
\hline $6 \mathrm{~b}$ & 3.02 & $6.93-7.52$ & 8.00 & $3.89\left(\mathrm{CII}_{3}()\right)$ \\
\hline $6 c$ & 3.10 & $6.92-7.22$ & 7.5 .3 & $3.92\left(2 \mathrm{ClI}_{3} \mathrm{O}\right)$ \\
\hline 6d & 3000 & $6.86-7.118$ & 7.95 & $3.80,3.81\left(2 \mathrm{ClI}_{3} \mathrm{O}\right)$ \\
\hline 6e & 2.95 & $6.8-7.11$ & 7.67 & $5.95\left(-\left(\mathrm{ClI}_{2} \mathrm{O}\right)-\right)$ \\
\hline $6 f$ & 2.95 & $7.14-7.54$ & 7.98 & \\
\hline $6 g$ & 2.90 & $7.95-7.18$ & 7.98 & $9.02(\mathrm{NII})$ \\
\hline $7 \mathbf{a}$ & 2.19 & $6.69-7.74$ & 7.08 & $3.09\left(\mathrm{Cll}_{3}\right)=\mathrm{N}$ \\
\hline $7 \mathrm{~b}$ & 2.20 & $6.91-7.35$ & 7.09 & $3.74\left(\mathrm{Cll}_{3} \mathrm{O}\right)$ \\
\hline $7 \mathrm{c}$ & 2.19 & $6.86-7.67$ & 7.0 .3 & $383,3.86\left(2 \mathrm{Cl} \mathrm{I}_{3} \mathrm{O}\right)$ \\
\hline $7 \mathrm{~d}$ & 2.19 & $6.93-7.31$ & 7.05 & $3.79\left(2 \mathrm{ClI}_{3} \mathrm{O}\right)$ \\
\hline $7 e$ & 2.19 & $6.88-7.26$ & 7.0 .3 & $5.95\left(-0 \mathrm{CII}_{2}()_{-}\right)$ \\
\hline $7 \mathrm{f}$ & 2.20 & $7.17-7.52$ & 7.47 & \\
\hline $7 \mathrm{~g}$ & 2.19 & $7.18-7.75$ & 7.35 & $0.02(\mathrm{NII})$ \\
\hline
\end{tabular}

resulted in absorption at $\$ 11 \mathrm{~nm}$ in cholroform. In increasing the number of the donating group as in the case in dyes $7 \mathrm{c}$. $7 \mathbf{d}$ and $7 \mathrm{e}$ the shift of absorption to longer wavelength compared to $7 \mathrm{~b}$ was observed (Table 6 ). The presence of the methoxy groups in position 3 and 4 showed bathochromic
Table 5. ${ }^{13} \mathrm{C}-\mathrm{NMR}-$ Data of Dicyanomethylene Derivatives 7a-g

\begin{tabular}{|c|c|}
\hline $\begin{array}{l}\text { Compound } \\
\text { No. }\end{array}$ & $\delta$ \\
\hline $7 a$ & $\begin{array}{l}26.78 .39 .85 .82 .63 .111 .67 .115 .44 .124 .16 .135 .21 \\
138.39 .143 .7 .151 .01 .167 .79\end{array}$ \\
\hline $7 b$ & $\begin{array}{l}26.21 .55 .80 .81,00.111 .30 .115 .33 .120 .5 .123 .67 \\
128.88 .132 .52 .134 .36 .143 .45 .161 .80 .170 .90\end{array}$ \\
\hline $7 c$ & $\begin{array}{l}25.91 .56 .05 .82 .63 .112 .63 .114 .40 .115 .44 .128 .23 \\
129.11 .142 .32 .145 .32 \cdot 145.57 .148 .71 \cdot 149.78 .170 .19\end{array}$ \\
\hline $7 d$ & $\begin{array}{l}26.11 .55 .61 .55 .80 .81 .00 \cdot 112.28 .115 .01 .115 .88 \\
124.11 .124 .2 .130 .48 .145 .09 .152 .05 .155 .23 \cdot 173.29\end{array}$ \\
\hline $7 e$ & $\begin{array}{l}26.78 .82 .63 .102 .02 .112 .55 .115 .44 .127 .92 .128 .72 \\
142.44,147.91 .148 .14,148.14,148.32 .170 .19\end{array}$ \\
\hline $7 \mathbf{f}$ & $\begin{array}{l}26.37,82.10,115.44,129.76,13.3 .59,134.32,1.36 .47 \\
142.50,142.5 .167 .79\end{array}$ \\
\hline $7 \mathrm{~g}$ & $\begin{array}{l}29.43,73.45,112.09,115.72,116.35,118.90,120.54 \\
123.65,127.12,129.23,131.26,13304,136.23,159.08\end{array}$ \\
\hline
\end{tabular}

Table 6. UV-Visible Spectral Data of Chalcones 6a-g and Their Analogues Dicyanomethylene Derivatives $7 \mathrm{a}-\mathrm{g}$

\begin{tabular}{|c|c|c|c|c|}
\hline \multirow{2}{*}{$\begin{array}{l}\text { I)e } \\
\text { No. }\end{array}$} & \multicolumn{3}{|c|}{$\lambda_{\text {111ax }}(\mathrm{nm})$} & \multirow{2}{*}{$\frac{\begin{array}{c}E_{1112 a x} \\
\left(\mathrm{dm}^{3} \mathrm{~mol} \mathrm{~cm}^{\prime} \mathrm{cm}\right)\end{array}}{\mathrm{CH}_{3} \mathrm{CN}}$} \\
\hline & $\mathrm{CHCl}_{3}$ & Acctonc & $\mathrm{CH}_{3} \mathrm{CN}$ & \\
\hline $6 a$ & 466 & 379 & 404 & 2360 \\
\hline $6 \mathrm{~b}$ & 379 & 376 & .372 & 3368 \\
\hline $6 c$ & .387 & 384 & 394 & 3067 \\
\hline $6 \mathrm{~d}$ & $4(1) 1$ & 395 & 383 & 6893 \\
\hline ge & 398 & - & 394 & 4004 \\
\hline $6 f$ & 376 & 365 & .372 & 5604 \\
\hline $6 \mathrm{~g}$ & 435,356 & $4.32,412$ & .353 & 1.361 \\
\hline $7 a$ & 542 & 533 & 543 & 5000 \\
\hline $7 \mathrm{~b}$ & 411 & 410 & $4(14.4$ & $33: 27$ \\
\hline $7 c$ & 450 & 467 & 440 & 1070 \\
\hline $7 \mathrm{~d}$ & 486 & 495 & 480 & 4091 \\
\hline $7 e$ & 445 & 461 & 450 & 852.3 \\
\hline $7 \mathrm{f}$ & 452 & 475 & 461 & 5941 \\
\hline $7 \mathrm{~g}$ & 489 & 481 & 506 & 6189 \\
\hline
\end{tabular}

shift compared to the presence of the methoxy groups in position 2 and 5 .

The introduction of the heterocrclic group such as dye $7 \mathbf{f}$ and $7 \mathrm{~g}$ which were prepared from 2-thiophenecarboxaldehyde and indole-3-carboxaldehyde respectively, showed bathochromic shift of visible absorption bands: dye $7 \mathrm{~g}$ absorbs at $489 \mathrm{~nm}$ with large band width $c a$. $180 \mathrm{~nm}$, which is a large bathochromic shift. The UV-Visible spectrum of dye $7 \mathbf{a}$ is shown in Figure 1 in acetonitrile as a representative example.

The large bathochromic shift of visible absorption of $4-$ dimethy lamino derivative 7 a (5+2 $1 \mathrm{~mm}$ in chloroform) relative to the less powerful donating groups such as the methoxy e.g. in $7 \mathrm{c}$ typifies the donor-acceptor character of the system. Increasing the solvent polarity causes bathochromic shift. indicating that the visible absorption band of dyes $7 \mathrm{a}-\mathrm{g}$ involves a $\pi$ - $\pi^{*}$ transition through the conjugated system. 


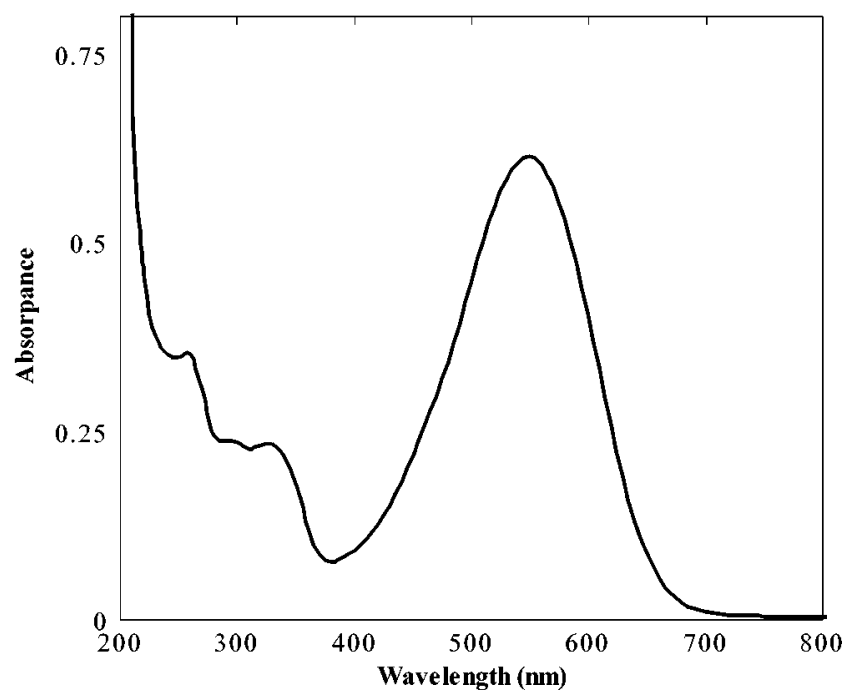

Figure 1. UV-Visible Spectrum ol Dye 7 a in acelonitrile.

The excited state receiving a large contribution from polar charge transfer is obtained by the migration of electrons from the nitrogen atom to the dicyanomethylene moiety (Scheme 4).

Comparison of the dicyanomethylene $7 \mathrm{a}-\mathrm{g}$ with their corresponding chalcones 6a-g showed the excellent electron accepting properties of the dicyanomethylene moiety in producing large bathochromic shifts (Table 6).

\section{Conclusions}

The solventless Knovenagel condensation of aromatic aldehydes and dicanomethylenecyclopentane afforded new 2.5-bisarylidene methine dyes. The subistitunets on the aromatic aldehydes play an important role in the colour of the new dyes.

\section{Experimental Section}

Melting points were recorded on a Thomas-Hover capillary melting apparatus without correction. IR spectra were taken on $\mathrm{KBr}$ disks on a Nicolet Magna 520 FTIR spectrophotometer. ${ }^{\mathrm{H}} \mathrm{H}-\mathrm{NMR}$ spectra were recorded in $\mathrm{CDCl}_{3}$ on a Brucker DPX $400 \mathrm{MHz}$. Spectrometer using TMS as an internal standard. Microanalysis were carried out using a Perkin-Elmer 240B analyzer. UV-Visible spectra was recorded on a Shimadzu 260 spectrometer.

Dicyanomethylenecyclopentane (5). Anhydrous sodium acetate $(10.0 \mathrm{~g} .0 .119 \mathrm{~mol})$ was added to a stirred solution of<smiles>N#CC(C#N)=C1CCCC1</smiles>

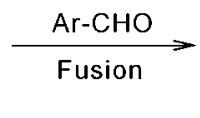<smiles>N#CC(C#N)=C1C(=C[AlH2])CCC1=C[AlH2]</smiles>

Scheme 3

cyclopentanone ( $10.0 \mathrm{~g} .0 .117 \mathrm{~mol})$ and malononitrile (7.86 g. $0.119 \mathrm{~mol})$ in absolute ethanol $(100 \mathrm{~mL})$ at $25^{\circ} \mathrm{C}$. The reaction mixture was stirred for 6 lurs. diluted with water and acidified to $\mathrm{pH} 3+$ with $6 \mathrm{~N}$ hydrochloric acid solution. The solid formed was filtered, washed with water followed by a small amount of ethanol. The crude product was recrystallized from ethanol to give 5 as off-white powder $(12.5 \mathrm{~g} .80 \%$ ), m.p. 83-85 ${ }^{\circ} \mathrm{C}$. Anal. Calculated for $\mathrm{C}_{8} \mathrm{H}_{*} \mathrm{~N}_{2}:$ C. $72.73: \mathrm{H}$. $6.06:$ N. 21.21 . Found: C. $72.56:$ H. $5.89 ;$ N. $21 .+3$.

General procedure for the synthesis of chalcones (6ag). A solution of sodium hydroxide $(20 \mathrm{~mL} .10 \%)$ in water was added dropwise to a well stirred solution of cyclopentanone $(0.05 \mathrm{~mole})$ and the appropriate aldehyde $(0.1$ mol) in ethanol $(25 \mathrm{~mL})$ at room temperature. The reaction mixture was stirred for two hours and then added to a mixture of ice and conc. hỵdrochloric acid. The precipitates were filtered, washed thoroughly with water and finally with ethanol, and dried. Analytical samples were recrystallized from ethanol (Table 1).

Preparation of the pyridine derivative (8). A solution of the chalcone $6 \mathrm{a}(0.5 \mathrm{~g} .1 .43 \mathrm{mmol})$. malononitrile $(0.1 \mathrm{~g}$. $1.43 \mathrm{mmol})$ and ammonium acetate $(0.33 \mathrm{~g} .4 .3 \mathrm{mmol})$ in absolute ethanol $(25 \mathrm{~mL})$ was heated under reflux for 3 hours. The solid product was collected by filtration and recrystallized from ethanol to give pyridine derivative 8 as orange powder $(0.48$ g. $82 \%)$. m.p. $220-222{ }^{\circ} \mathrm{C}$. Anal. Calculated for $\mathrm{C}_{26} \mathrm{H}_{2}: \mathrm{N}_{5}:$ C. $76.28 ; \mathrm{H} .6 .60 ; \mathrm{N} .17 .11 \%$. Found: C. 76.35; H. 5.89: N. 17.37. $v_{\text {mlik }} / \mathrm{cm}^{-1} 3350.3227$ $\left(\mathrm{NH}_{2}\right), 2215(\mathrm{CN}) .1580(\mathrm{C}=\mathrm{C})$.

Preparation of the pyran derivative (9). A mixture of chalcone $6 \mathrm{a}$ ( $1.5 \mathrm{~g}$. $4.3 \mathrm{~mm}$ ) $)$, malononitrile $(0.28 \mathrm{~g} .4 .3$ $\mathrm{mmol}$ ) and absolute ethanol $(20 \mathrm{~mL})$ in the presence of a few drops of piperidine was refluxed in a water bath for $5 \mathrm{hrs}$. The amount of solvent was reduced by distillation under reduced pressure and allowed to cool. The precipitated solid was collected by filtration and crystallized from ethanol to give pyran 9 as yellow crystals ( 1.5 g. $85 \%$ ). m.p. 153-155 ${ }^{\circ} \mathrm{C}$. Anal. Calculated for $\mathrm{C}_{26} \mathrm{H}_{28} \mathrm{~N}_{-} \mathrm{O}:$ C. $75.73 ;$ H. 6.80: N. 13.59. Found: C. $75.65 ;$ H. 6.98: N. 13.36: 'H NMR $\delta 2.02$. $2.41\left(4 \mathrm{H}, \mathrm{m}, \mathrm{CH}_{2}\right) .2 .91 .3 .01\left(12 \mathrm{H} . \mathrm{s} .\left(\mathrm{CH}_{3}\right)_{2} \mathrm{~N}\right)+.2+(1 \mathrm{H}$.<smiles>CN(C)c1ccc(/C=C2\CCC(=O)C(C)(C#N)C2(C#N)C#N)cc1</smiles><smiles>CN(C)c1ccc(C=C2CC/C(=C\c3ccc(N(C)C)cc3)C2=C(C#N)C#N)cc1</smiles> 
s. Py гап-4H), 6.72-8.19 (8H, m, aromatic protons), $6.89(1 \mathrm{H}$, s. olefinic proton); $v_{\text {пla }} \mathrm{cm}^{-1} 3380.3290\left(\mathrm{NH}_{2}\right), 2220(\mathrm{CN})$.

General procedure for the synthesis of dyes $(7 \mathrm{a}-\mathrm{g})$. A mixture of cyclopentylidenemalononitrile (1 mul) and aromatic aldelyyde ( 2 mmol) was heated in an oil bath for 6 lirs. After cooling the reaction mixture to room temperature. ethanol $(25 \mathrm{~mL})$ was added and the precipitate was filtered and recry stallized from acetic acid (Table 2).

Acknowledgements. The financial support for this research from the scientific research council of King AbdulAziz University is gratefully acknowledged.

\section{References}

1. Grilliths. J. Run: Prog Coloration. 1981. H. 37.
2. Wehry. E. L. Mokkm Fhonescence Spectroscopy. H'lenum l'ress: Heyden. London. Nen Yorh. 1976.

3. Allen. R. L. M. Colonr Chemismy: Nelson. Londen. 1971.

4. Bronn. G. I1. Photochomism: Wiler-Interseienes: New York. 1971

5. Fabian. I.: I Hartmann, II. Light Athsorption of Oryanic colomants: Spriger Verlag: Berlin. 1980.

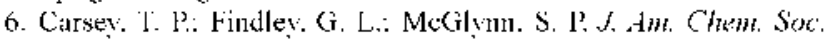
1979. 101. 4502 .

7. Ioutty: R. O. I aw: K. Y.J. Phys (hem 1953. 49, 1375.

8. Irick, G.: Straley. J. M. Tert Chem C'olor 1969. 1. 178.

9. Irick, G. J. (Wem Fing. Data 1971, 16.118.

10. Asiri. A. M. Dies and Pigments 1999. 42. 209.

11. Attia. A.: Michael. M. Ihammazie 1998. 37. 551.

12. Jager. H. Chem. Ber 1962. 95.242.

13. Ie Guillation. G. Acad Sci. 1972, (274, 895. [C Whem thst. m 1972, 76. 15.300s].

14. Prajapati. D.: Sandhu. I. S. J. Chem. Soc. Ferkin Trons. I 1993. 739. 